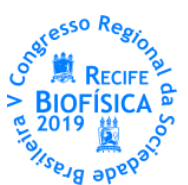

\title{
APLICAÇÃO DE BIOSSENSORES BASEADOS EM MAGNETORRESISTÊNCIA GIGANTE PARA ENSAIOS CLÍNICOS EM MULTIPLEX
}

\author{
Guilherme Santana Barbosa ${ }^{1}$; Agenor Tavares Jácome Junior ${ }^{1}$
}

${ }^{1}$ ASCES UNITA - Centro Universitário Tabosa de Almeida (Avenida Portugal, 445. Caruaru, PE)$$
\text { RESUMO }
$$

Introdução: Biossensores são dispositivos que transformam reações químicas e biológicas em sinais detectáveis e equivalentes à concentração do analito, sua relevância atual deve-se à estabilidade, sensibilidade e possível praticidade na análise de múltiplos alvos num ensaio. A magnetorresistência gigante (MRG) é um princípio da física de distribuição de campo magnético que, aplicado a biossensores, detecta quantidades precisas de partículas magnéticas ligadas ao analito num chip pela interação destas com o efeito spin-órbita, resultando em queda de resistência de forma detectável. Objetivos: Verificar na literatura as mais frequentes aplicações clínicas de ensaios multiplex com biossensores por MRG. Metodologia: Refere-se a uma revisão de literatura a partir de 22 artigos de língua inglesa obtidos nas bases de dados online NCBI e ScienceDirect entre os anos de 2010 e 2019, tendo como descritores biosensors, GMR e multiplex. Desenvolvimento: 0 emprego atual de partículas magnéticas, para além de procedimentos in vivo, auxilia ensaios biomédicos nos processos de separação diagnóstica e na quantificação de analitos por ensaios imunomagnéticos em sandwich; imobilizando elementos (DNA, RNA e proteínas) e ligando-os a anticorpos ou sondas de ácidos nucleicos marcados com partículas magnéticas. Zhang et al., em 2013, conseguiu determinar concentrações muito baixas das quatro principais nanopartículas magnéticas (óxido de ferro, ferritna de cobalto, ferritina de níquel e ferritina de zinco e níquel) por sensor de MRG, e obteve êxito com quantificações de até $0.1 \mathrm{ng}$ sem necessidade de modificação das partículas. Alguns estudos como os de
\end{abstract}

Krishna et al. e Xu et al. utilizaram-se de sondas sintéticas e anticorpos monoclonais, por magnetorresistência, correspondentes a fragmentos amplificados do vírus da Influenza A e proteínas nucleares do Papiloma Humano (HPV), respectivamente, em chips de DNA, que chegaram a mensurar materiais escassos de até $10 \mathrm{ng}$, e em arranjos proteicos que, comparado ao ELISA, apresentaram sensibilidade de detecção maior em até 2,6 vezes. Ensaios multiplex para a determinação de um perfil de marcadores tumorais também foram descritos, Gao et al. em 2018, por exemplo, confeccionou um dispositivo de detecção simultânea de 12 marcadores tumorais (AFP, CEA, CYFRA21-1, NSE, SCC, PG I, PG II, CA19-9, PSA total, PSA livre, B-hCG-livre e $\mathrm{Tg}$ ) com duração de 15 minutos e dosagens altamente precisas, outros testes dessa natureza são hoje restritamente comercializados como uma alternativa de suporte de rastreamento precoce de tumores; Lee, et al. em 2016 realizou um ensaio para estudar a relação da presença de autoanticorpos, associados à rede de quimiocinas, em pacientes com Lúpus Eritematoso Sistêmico (LES) com o score alto para desregulação de quimiocinas e intérferons, e pode determinar 13 tipos com significância $p>0.05$. Conclusão: Apesar da comprovação do benefício relativo à quantificação de múltiplos analitos nas análises clínicas, o custo de biosensores baseados em MRG e a disponibilidade dessas plataformas ainda são restritos. 0 melhoramento de partículas magnéticas e da acurácia dos sensores têm mostrado potencializar o potencial de detecção desse método. 